\title{
Poverty and Artificial Sustainability A research on the Structure and Dynamics of South America
}

\author{
Luciano Gallón \\ Universidad Pontificia Bolivariana (Medellin, Colombia) \\ luciano.gallon@upb.edu.co
}

\begin{abstract}
In 1950, 113 million people lived in South America, in 2008, 385 million, more than three times. Half of them live in poverty. In 2050, about 485 million people will be living there. Contemporary population dynamics figures on a global average show that by each birth in a rich family there are 38 in poor families. Then it's necessary to think on new social, ecological and economic systems models to analyze and synthesize their possible sustainability from two perspectives: natural and artificial, and to research on how they are possible and behave. This paper shows the process of building, with the help of first and second order cybernetics tools, a theoretical and practical framework for modeling South America using Systems Dynamics and explores questions such as: Is it possible to reduce poverty following a sustainable path? What is the kind of steady state behind the sustainability ideas? In what sense is it possible to talk of artificial sustainability? What relationship can be found between the scales of space and time of the human perspective and of the sustainability and the dynamics of the new social equilibriums? How such exploration enriches the understanding of social systems and human behavior? What contributions can be offered from such analysis and synthesis to contribute to sustainability? How can the structure and dynamics of South America helps to answer those questions? The obtained results will serve to discover possible inconsistencies and counterintuitive behaviors in traditional conceptions of poverty, development and sustainability.
\end{abstract}

\section{Introduction}

According to United Nations, in 1950113 million people lived in South America, a number that has reached about 393 million in 2010, almost 3.5 times and half of them live in poverty. For 2050 the estimates reveals that about 483 million people will be living in that region of planet Earth (United Nations, 2009). 
The analysis of the population dynamics shows that, approximately and on a global average for 2008, by each birth in a rich family there are 38 in poor families (Population Reference Bureau, 2008). That kind of dynamics reveals the necessity to think new models of social, ecological and economic systems in which a particular population is developing to be able to analyze and synthesize their possible scenarios of sustainability.

But to answer if it is possible to reduce poverty in South America following a sustainable path, it is needed not only a model, but a new set of theoretical and practical tools to investigate it.

\section{Longevity and Sustainability}

The scales of space and time with which the humans observes, lives and constructs their world, are ones of the elements that determine the human perspective. The scales of space and time with which the systems observe, constitute and construct their longevity, are ones of the elements that determine the sustainability.

We lived in a time in which as much the human perspective as the sustainability are entering in evolutionary processes with position, direction, speed and acceleration dynamics in scales of space and time aliens to the human perception and experience, facing two types of steady states, the nominal or natural (e.g.: the human body in the Earth biosphere is made for living 30 to 40 years. The normal life expectancy with subsistence food, no medical care and no industrialization is 28 year on average (Meadow, Meadows, \& Randers, 2004)) and the real or artificial (e.g.: that nowadays human life expectative is more than 60 years and in some countries more than 80 years (United Nations, 1990-2009)).

As exposed in (Gallón, 2009) there is a simple, clear and imperative relationship between subsystems' 'local' sustainability and meta-system's 'global' sustainability, and when the fine and delicate equilibrium is modified by any type of change on any of the 'local' longevities by any kind of mean (e.g. natural selection, technology, over population, etc.), the hole system structure and dynamics could be modified (Costanza \& Patten, 1995). That means that there exists some kind of longevity trap and, within and apparent better 'local' sustainability (on longevity terms), the meta-system, supposed to be an open system, is inevitable conducted towards a new reference steady state (von Bertalanffy, 1976). 
For the propose of this paper, it is of particular interest to take a closer look at longevity by population dynamics in a local open system, so let's take a look at the phases of population growth (Fernández, 2007) with the Population Dynamics graph (see Figure $1)$.

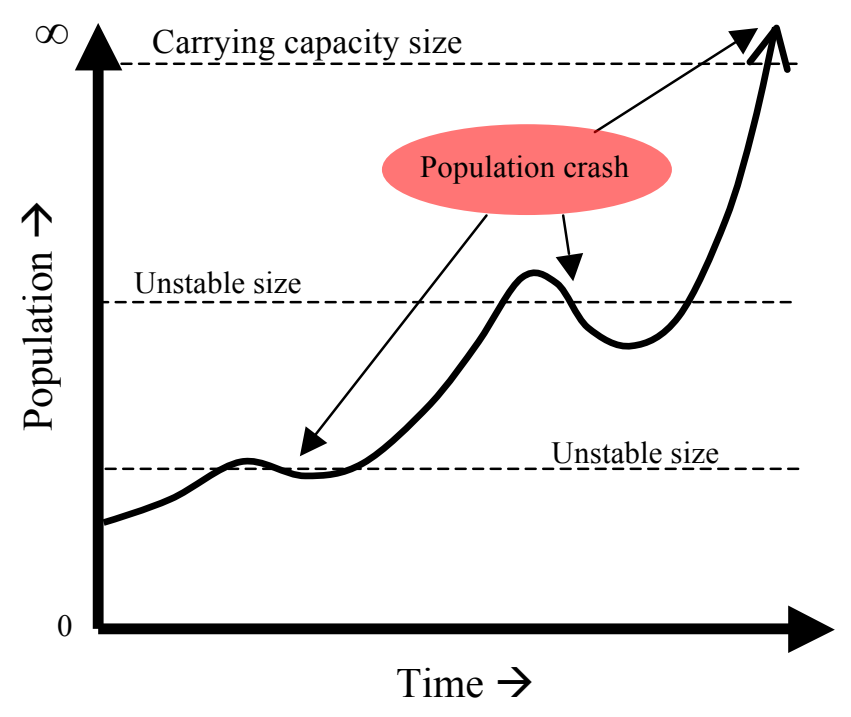

Figure 1. Population Dynamics.

The graph can be characterized by four possible phases depending on historical events:

- Phase I. A continuous gradual slope in population increase that corresponds to the living conditions of each period with their gradual advances and setbacks.

- Phase II. A significant population increase attributed to improved overall living conditions after a major setback to which, as a major catastrophe, some structural changes occur on the system after reaching an unstable size.

- Phase III. A continuous population growth due to advances based on the previous phase's significant structural and dynamic changes.

- Phase IV. Projects into the future the current exponential growth path towards the next setback either other unstable size o a major carrying capacity limit.

The general Malthus population law states that Population, when unchecked, increases in geometric ratio. So, the geometric (exponential) growth model was only intended as a law of nature governing unchecked population growth. Much of the rest of Malthus' essay is an exploration of those factors which check growth (Coutts, 2009) and are 
called the Malthusian Positive Checks (MPC), some kind of systemic natural suppressive forces on population increase related to every phase (See Table 1).

Table 1. Malthusian Positive Checks.

Source: (Fernández, 2007)

\begin{tabular}{|c|c|c|c|c|}
\hline Influence $\backslash$ Phase & $\mathbf{I}$ & II & III & IV \\
\hline Environment (Resource consumption/Climate change) & $+/-$ & - & - & $-/+?$ \\
\hline Social (Urbanization) & + & $+/-$ & - & $-/-$ \\
\hline Economic (Needs to Wants) & + & $+/-$ & - & $-/-$ \\
\hline Technology (Infrastructure) & $\mathrm{N} / \mathrm{A}$ & $+/-$ & - & $-/-$ \\
\hline Government (Wars) & + & $+/-$ & - & $-/+?$ \\
\hline Education & + & $+/-$ & - & $-/-$ \\
\hline Agriculture & + & $+/-$ & - & $-/-$ \\
\hline Medicine (Hygiene/Disease/Pandemics/Pestilence) & + & $+/-$ & - & $-1+$ \\
\hline+ (positive) Totals & 7 & 7 & 0 & 3 \\
\hline - (negative) Totals & 1 & 8 & 8 & 8 \\
\hline
\end{tabular}

As result, for example, the human population growth is on phase III and unchecked, and its longevity also growth and, of course, the local sustainability has change setting new conditions for a change on the global system steady state towards a new reference threshold.

\section{Steady and Dynamic Equilibrium States}

Equilibrium (Homeostasis) is the property of a system, either open or closed, that regulates its internal environment and tends to maintain a stable, constant condition. Steady state is a more general situation than dynamic equilibrium. If a system is in steady state, then the recently observed behavior of the system will continue into the future. In stochastic systems, the probabilities that various different states will be repeated will remain constant (Wikipedia, 2010).

In many systems, steady state is not achieved until some time has elapsed after the system is started or initiated. This initial situation is often identified as a transient state, start-up or warm-up period. While a dynamic equilibrium occurs when two or more reversible processes occur at the same rate, and such a system can be said to be in steady state, a system that is in steady state may not necessarily be in a state of dynamic equilibrium, because some of the processes involved are not reversible (Wikipedia, 2010).

As mentioned above, those $20+$ years above the human natural 30 to 40 years steady 
state longevity are a powerful source of imbalances/unsustainability because affect the balances of inferior and superior space and time scales of all the life span inhabiting or shaping the biosphere of the Earth system (Included the Planet itself). Then it is necessary to think on sustainability from two perspectives: natural and artificial steady states, and to research on how they are possible and behave (see below for a discussion on natural vs. artificial).

The harsh reality is that as much you as I (and almost everybody) want to live those 20+ more years, and so the harsh reality is that we must research and propose some sort of sustainability in a new state of artificial steady state, and that is the point. There are other people, the ones that think that tribal or the so-called primitive peoples must be the reference for sustainability. They want all of us returning to live as the noble savage with their millenarian and traditional cultures as the path to return to a 'natural' balance steady state, but, are we (are you?) disposed to return to a human life longevity of about 30 to 40 years?

The relationships that exist between population growth demands on natural resources and environmental degradation are complex (Fernández, 2007). There are two types of dynamic drivers: First, in developing countries, the resources essential to individual survival needs are in small or reduced availability and are estimated to be $20 \%$ of global resources and energy, but the large and rapidly increasing number of people, estimated at $80 \%$ of the global population, tend to overwhelm and deplete the nonrenewable resources rapidly. Second, in developing and highly developed nations, the numbers of population and population growth are small, relative to the total global population, and estimated at $20 \%$, but have a higher standard of living consuming $80 \%$ of the global resources and energy.

The dynamic consequences of those two drivers are: First, over population footprint on non-renewable resources, which includes minerals and fossil-fuels that are present in limited supplies and are depleted by use (mostly by developed countries) and, on renewable resources, that can be used forever as long as they are not overexploited in the short term over the ecosystem services capabilities (such as by developing populations that depend on these resources for daily needs and survival). In this case even renewable resources are termed as potentially renewable. Second, over consumption footprint as the higher standard of living of population carries a higher resource and energy consumption producing an exponential depletion of resources and waste disposal with the accompanying degradation of the environment.

Even worst (See Figure 2), the structure and dynamics of population mobility caused by Needs-to-Wants forces shows that large masses of population, rapidly transitioning 
from a developing to a developed state, and estimated at an approximate annual shift of $5-10 \%$ of the global population, further aggravates the resource consumption and environmental degradation figures (Fernández, 2007)

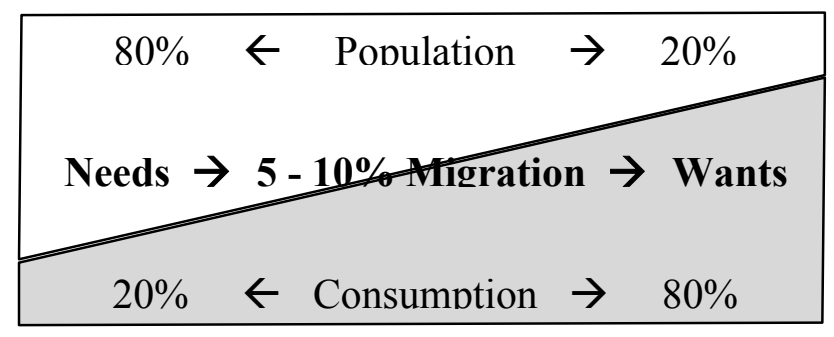

Figure 2. Needs-to-Wants Migration Conceptual Model Source: (Fernández, 2007)

This is a major change on the steady state threshold point and can be summarized as things are getting better and better, worse and word faster and faster considering that, simultaneously, the knowledge and technology infrastructures are getting better, more efficient and pervasive, following exponential paths.

\section{Natural vs. Artificial Sustainability}

First, let's try to understand the differences between natural and artificial. In a recent blog entry (Amit, 2008) wrote about natural and artificial occurrences in what we observe. It starts asking what we can call artificial:

By default, whatever which exist, is natural. Something which can be said as unnatural would be something which is impossible to occur and which cannot exist at all. It means that, to state something or someway as better than others because it is 'natural' is redundant and wrong. Also, to speak of some existing phenomenon as artificial or unnatural is absurd. So, artificial can never be unnatural, what is it then?

Then he describes the observer position with this analysis (added bold):

Irrespective of one is creationist or evolutionist, human cannot be said as unnatural. Artificial is that, which is a natural product of human efforts by means of human intelligence, and again human intelligence is also a part of 
nature and no human intelligence can ever break any natural law [...]. So what is artificial intelligence? It must be clear that artificial intelligence is nothing like unnatural and it is completely natural because to say something as beyond nature or unnatural is to assert that it is supernatural and that is impossible.

So then, what are the main characteristics structures of the natural?

Nature is beyond biases, it is neutral. Everything is neutral despite the consequences of it, irrespective of how common or rare it is, when it occurs or doesn't occurs, whether it is profitable or detrimental, good or bad for human or other species, and so on. That which is natural, which occurs or exists, cannot be assumed to be good or bad by virtue of it being natural. Nature doesn't have any intrinsic value. To say that which is natural is inherently good or bad means that everything is either good or bad, and that is absurd.

And, what about the dynamics of what we call natural?

Also, nature is not static, it is dynamic, and it is in a state of constant flux. So, whatever is natural doesn't necessarily mean that it is universal or inevitable or permanent. It means that whatever is current in present scenario can very well be outmoded rendered and archaic in the future. Thus, appealing to the past as 'natural' is simply an irrational argument. What once was natural can be outdated over time, and what once was just a dream in past can be natural in present. The present and future is no less 'natural' and naturalness of things in the context of past, present and future is irrelevant.

Now let's take a sociocybernetics look of the implication of the natural/artificial duality, following again (Amit, 2008) considerations on world system radicals, conservatives and socialist observers:

The irrational concept of natural/artificial duality is manifested in the arguments of the primitivists, anti-civilizationists, and radical environmentalists. The contemporary science and technology and expanded horizon of human labor is criticized as 'unnatural' while the more archaic and self-sufficient ways of living are 'romanticized' as 'natural'. Human civilization is signified as inherently against the nature and human is considered as the 'destroyer of nature'. Radical egalitarians also uses same dichotomy as they suggest egalitarianism as 'natural' while hierarchy is considered to be 'unnatural'.

The conservatives also try to use this irrational concept of artificial/natural 
duality. Dogmatic class hierarchy, religious authority, racism, casteism, nationalism, linguistic preferences and biases have been characterized as 'the natural order' as if they are the unalterable laws of nature and intrinsic authorities and deviations from them is considered as 'unnatural', anyone going against them is considered as antagonistic with nature. Conservative philosophy strongly appeals to tradition as being 'natural', and divergence from tradition such as homosexuality, live-in relationships, sodomy, transvestites, secularism, multiculturalism, inter-caste, inter-religion, inter-continental marriages and sexual relations are assumed as 'unnatural'. Even many of them consider sexeducation in schools is immoral and unnatural.

Socialistic and statist theory supporters also use this artificial/natural duality to assert that a centralized political system involves man existing in 'the state of nature', and the rise of centralized political organization is considered as some 'inevitable natural law'. While freedom is considered as 'unnatural' and anyone rejecting the idea of statist government is considered as opposed to 'nature', miniarchist, anarchists are considered as unnatural or are compared with a primitives 'natural state' before centralized political organization took place.

Then the problem of natural/artificial duality is more important than thought before but not because the inherent discussion it entails but because it distract and diverts the attention out of the big problem (Amit, 2008):

As a matter of fact all these various types of social phenomenon and organization can certainly be analyzed as profitable as or more beneficial than other, yet, none can be said as 'unnatural. In fact, whether or not they are 'natural' is totally irrelevant to such an appraisal because they all are 'natural' and none is antinatural or supernatural. The concept of duality between artificial and natural is a misnomer and is irrational which diverts the real points of contentions.

For example (Dawkins, 2001) gives a sociocybernetics clear and simple description of the natural/artificial duality implication on sustainability when an observer uses an anachronistic natural point of view:

People of goodwill [...] are rightly preoccupied with sustainability, with renewable resources, with taking the side of the future against short-term private gain. Not surprisingly, the rhetoric of such people tends to place nature on a pedestal, where every prospect pleases and only man is vile. [...] it is not like that, quite the contrary. But [...] this is not a reason for despair, nor does it mean that 
we should cynically abandon the long-term future, gleefully scrap the Kyoto Accords and similar agreements, and get our noses down in the trough of shortterm greed. What it does mean is that we must work all the harder for the longterm future, in spite of getting no help from nature, precisely because nature is not on our side.

There is a confusion here with another strand of rhetoric - that of the noble savage. Tribal, so-called primitive, peoples have been thought to be in tune with nature, conserving stocks for the future, taking only what they need, living in harmony with the land, respecting their prey even as they kill them. This rhetoric falls foul of the facts. Unfashionable though it may be to say so, it is looking more and more likely, for example, that the magnificent Pleistocene mega fauna of North America died out as a direct consequence of the arrival, perhaps some 13,000 years ago, of hunter gatherers, who had walked across what was then the Bering land bridge. Primitive agriculture too tends to be of the slash and burn variety, which is the very opposite of sustainable, the very opposite of forwardlooking.

Humans are no worse than the rest of the animal kingdom. We are no more selfish than any other animals, just rather more effective in our selfishness and therefore more devastating. All animals do what natural selection programmed their ancestors to do, which is to look after the short-term interest of themselves and their close family, cronies and allies. If any species in the history of life has the possibility of breaking away from short-term Darwinian selfishness and of planning for the distant future, it is our species. We are earth's last best hope, even if we are simultaneously the species most capable in practice of destroying life on the planet. When it comes to taking the long view we are literally unique. No other species is remotely capable of it. If we do not plan for the future, no other species will. 


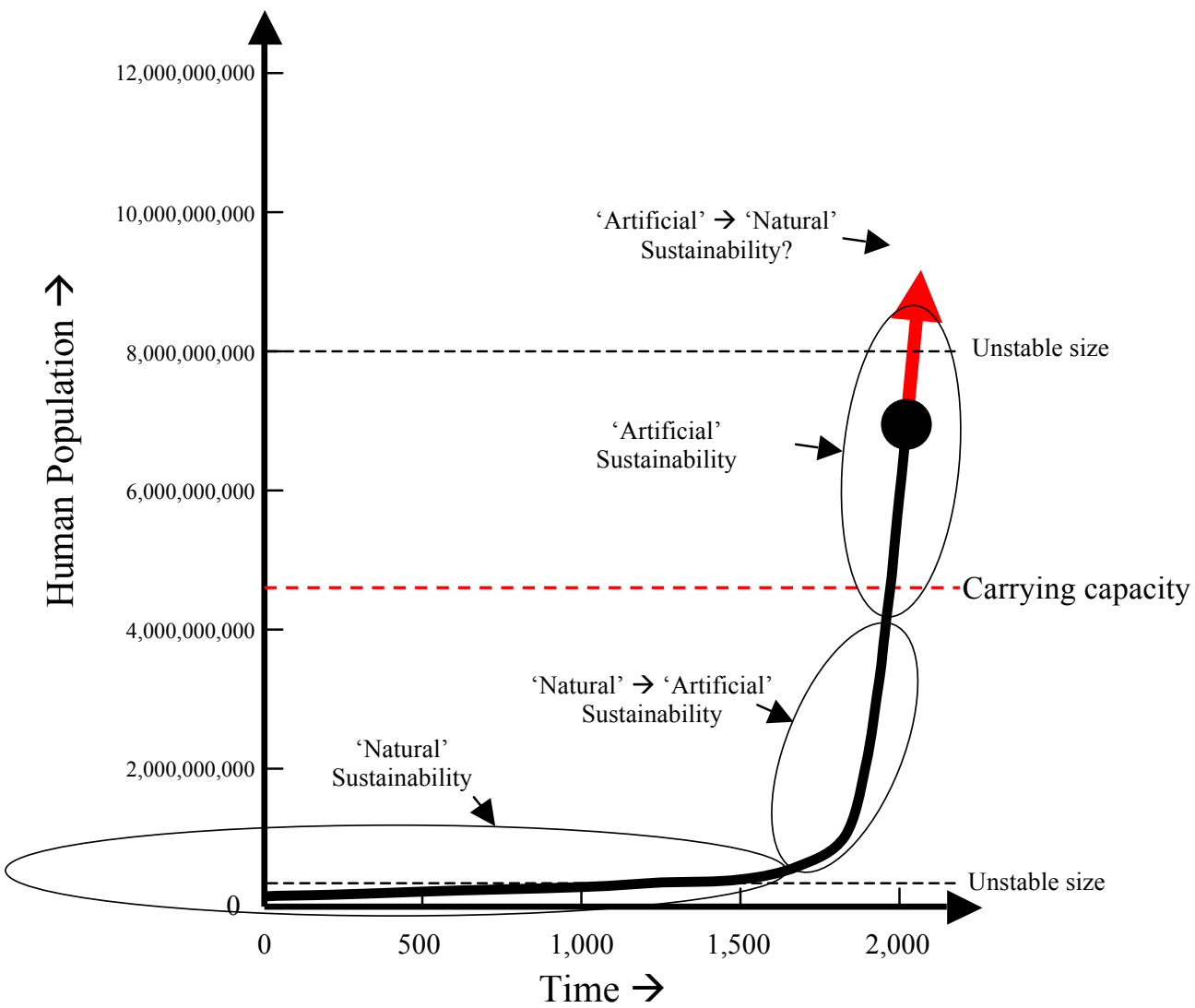

Figure 3. Human Population and Natural vs Artificial Sustainability.

As Figure 3 shows, it is not up until no more that $100-150$ years ego than nature has its 'own' sustainability action on human population longevities and growth. Up until recently, it functioned through the conditions that caused child-birth-death, motherbirth-death, pandemics, epidemics, diseases, plagues, famine, droughts, tornados, hurricanes, and blizzards, with impetus added by human social behavior and practices of wars, slavery, and genocide that created a fertile ground for death, disease, and plagues (Fernández, 2007).

But human intelligence advances on all fronts of knowledge created new structural and dynamic conditions for human total fertility rate decrease and longevity increase and it is possible to see the effects of a 'new' sustainability set of actions as medical and cultural methods, education and voting rights of women, migration to urban environments, concerted efforts of governments to limit population growth, increased 
affluence and the influential forces of global communication, among others (Fernández, 2007).

It is in that sense that is possible to say that we're moving from natural to artificial sustainability structures and dynamics and that it is necessarily to have new human ways of implications on solving the problems we face ahead because human population exponential growth has concomitants exponential growths in wealth, demographics, resource consumption, material depletion, waste and pollution generation, all within a resource-finite semi-closed system that we call Earth.

So let's move to South America to take a look at its structure and dynamics and to see what is happening with its population and human conditions as possible scenarios for research on poverty and artificial sustainability.

\section{South America}

South America is a region of the planet Earth with an approximated area of 17.840.000 $\mathrm{km}^{2}$, a $12 \%$ of the emerged Earth. From its Northern end to its Southern end there are about $7.500 \mathrm{~km}$ (linear) and from its Western end to its Eastern end about $5.100 \mathrm{~km}$ (linear). It is only connected with another continental earth emerged zone of the planet, Central America, through the lands that conform the so called Darién in the border between Colombia and Panamá, thus counting with more than $20.000 \mathrm{~km}$ of coasts in the Pacific and Atlantic oceans. The 12 South American countries borders plus France (French Guyana) are shown in Figure 4.

Its topography is of extremes, because the Andes mountain range crosses from north to south throughout $7.500 \mathrm{~km}$ with a height average of $4.000 \mathrm{~m}$, and with heights of up to $6.982 \mathrm{~m}$ in the Aconcagua tip. Thus, there are narrow mountainous humid forest earths to the

Figure 4. South America political division.

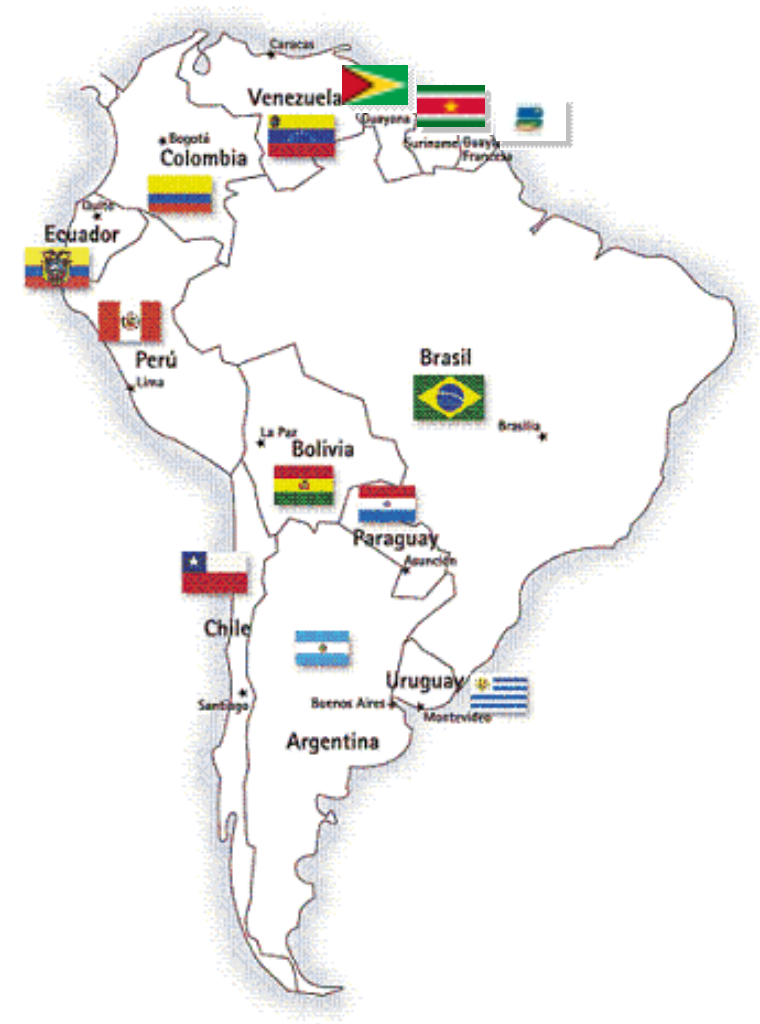


West of the Andes forming coast with the Pacific Ocean, and immense plains of tropical forest, the Amazon and the Pampas, to the East of the Andes, until forming all the coasts with the Atlantic Ocean. This way, the terrestrial or fluvial connectivity between the West and East is practically nonexistent, and is only viable via marine or areal transportation. This geographic reality can serve as explanation of the origin and development of the locations of the main human settlements in the region as is shown in Table 2.

Table 2. Main human settlements in South America.

Source: Google Earth and Wikipedia.

\begin{tabular}{|c|c|c|c|c|c|c|}
\hline Country & City * & $\begin{array}{l}\text { Foundation Year } \\
\text { (Conquest ref.) }\end{array}$ & $\begin{array}{l}\text { Population } \\
\text { (2005 est.) }\end{array}$ & $\begin{array}{l}\text { Altitude } \\
\text { (m) }\end{array}$ & $\begin{array}{c}\text { Distance } \\
\text { to Ocean } \\
\text { (linear } \mathbf{k m} \text { ) }\end{array}$ & $\begin{array}{l}\text { River to } \\
\text { Ocean }\end{array}$ \\
\hline \multirow{3}{*}{ Argentina } & Buenos Aires & 1,536 & $12,789,000$ & 1 & 0 & Plata \\
\hline & Córdoba & 1,573 & $1,372,000$ & 700 & 620 & No \\
\hline & Rosario & 1,724 & $1,242,000$ & 30 & 250 & Paraná \\
\hline \multirow{3}{*}{ Bolivia } & Santa Cruz de la Sierra & 1,561 & $1,540,000$ & 410 & 750 & No \\
\hline & El Alto & 1,940 & 860,000 & 4,150 & 300 & No \\
\hline & $\mathrm{La} \mathrm{Paz}^{* *}$ & 1,548 & 835,000 & 3,700 & 315 & No \\
\hline \multirow{3}{*}{ Brasil $^{* * *}$} & São Paulo & 1,554 & $10,990,249$ & 760 & 55 & No \\
\hline & Rio de Janeiro & 1,565 & $6,161,047$ & 0 & 0 & No \\
\hline & Salvador & 1,534 & $2,948,733$ & 0 & 0 & No \\
\hline \multirow{3}{*}{ Chile } & Gran Santiago & 1,541 & $6,000,000$ & 570 & 100 & No \\
\hline & Gran Concepción & 1,550 & 950,000 & 12 & 0 & Biobío \\
\hline & Gran Valparaíso & 1,536 & 850,000 & 5 & 0 & No \\
\hline \multirow{3}{*}{ Colombia } & Bogotá & 1,538 & $6,840,116$ & 2,600 & 360 & No \\
\hline & Medellín & 1,541 & $2,223,078$ & 1,540 & 195 & No \\
\hline & Cali & 1,536 & $2,068,386$ & 995 & 80 & No \\
\hline \multirow{3}{*}{ Ecuador } & Guayaquil & 1,538 & $2,157,853$ & 4 & 0 & Guayas \\
\hline & Quito & 1,534 & $1,516,353$ & 2,850 & 160 & No \\
\hline & Cuenca & 1,557 & 305,772 & 2,550 & 90 & No \\
\hline \multirow{3}{*}{ Guyana } & Georgetown & 1,781 & 134,599 & 0 & 0 & Demerara \\
\hline & Linden & 1,970 & 29,521 & 48 & 86 & Demerara \\
\hline & Nueva Ámsterdam & 1,740 & 17,526 & 6 & 4 & Berbice \\
\hline \multirow{3}{*}{$\begin{array}{l}\text { Guyana } \\
\text { (Francia) }\end{array}$} & Cayena & 1,643 & 62,926 & 0 & 0 & Cayena \\
\hline & Matoury & 1,656 & 29,347 & 0 & 1 & Cayena \\
\hline & Kourou & 1,645 & 23,813 & 2 & 0 & Kourou \\
\hline \multirow{3}{*}{ Paraguay } & Asunción & 1,537 & 525,662 & 43 & 900 & De la Plata \\
\hline & Ciudad del Este & 1,957 & 320,700 & 185 & 610 & Paraná \\
\hline & San Lorenzo & 1,775 & 287,977 & 126 & 885 & De la Plata \\
\hline \multirow{3}{*}{ Perú } & Lima & 1,535 & $7,870,000$ & 110 & 0 & No \\
\hline & Arequipa & 1,540 & $1,200,000$ & 2,335 & 86 & No \\
\hline & Trujillo & 1,534 & 820,000 & 34 & 0 & No \\
\hline \multirow{3}{*}{ Surinam } & Paramaribo & 1,603 & 242,946 & 3 & 0 & Surinam \\
\hline & Lelydorp & 1,905 & 17,000 & 6 & 10 & Surinam \\
\hline & Nueva Nickerie & 1,879 & 13,410 & 2 & 4 & Corentyne \\
\hline \multirow{3}{*}{ Uruguay } & Montevideo & 1,726 & $1,269,648$ & 43 & 0 & No \\
\hline & Salto & 1,756 & 99,072 & 48 & 290 & Uruguay \\
\hline & Paysandú & 1,749 & 84,162 & 42 & 185 & Uruguay \\
\hline \multirow{3}{*}{ Venezuela } & Caracas & 1,567 & $3,276,000$ & 900 & 12 & No \\
\hline & Maracaibo & 1,529 & $2,063,670$ & 6 & 0 & No \\
\hline & Valencia & 1,555 & $1,385,202$ & 479 & 32 & No \\
\hline
\end{tabular}


The only great terrestrial route of the continent is the Pan-American road that crosses it south to north by the mountain range of the Andes. Three great fluvial routes exist, the Amazon, Orinoco and Parana rivers that, although counting with more than $12.000 \mathrm{~km}$ of channels, they have not been determining factors of location of human settlements or remarkable processes of industrialization. On the other hand, Table 3 shows the data of the human population growth in the 12 South American countries and in Table 4 it is possible to observe that it has been an accelerated and significant growth in the last 55 years. Finally, Table 5 shows the population growth projections until 2050.

Table 3. South America Population Growth (in millions) 1950 - 2005.

Source: (United Nations, 2009)

\begin{tabular}{|c|c|c|c|c|c|c|c|c|c|c|c|c|}
\hline Country & 1950 & 1955 & 1960 & 1965 & 1970 & 1975 & 1980 & 1985 & 1990 & 1995 & 2000 & 2005 \\
\hline Argentina & 17.2 & 19.0 & 20.7 & 22.3 & 24.0 & 26.0 & 28.2 & 30.2 & 32.5 & 34.8 & 36.9 & 38.7 \\
\hline Bolivia & 2.7 & 3.0 & 3.4 & 3.7 & 4.2 & 4.8 & 5.4 & 6.0 & 6.7 & 7.5 & 8.3 & 9.2 \\
\hline Brasil & 54.0 & 62.9 & 72.7 & 84.3 & 96.0 & 108.1 & 121.6 & 136.1 & 149.6 & 161.7 & 174.2 & 186.1 \\
\hline Chile & 6.1 & 6.8 & 7.6 & 8.7 & 9.6 & 10.4 & 11.2 & 12.1 & 13.2 & 14.4 & 15.4 & 16.3 \\
\hline Colombia & 12.0 & 13.8 & 16.0 & 18.6 & 21.3 & 24.0 & 26.9 & 30.0 & 33.2 & 36.5 & 39.8 & 43.0 \\
\hline Ecuador & 3.4 & 3.9 & 4.4 & 5.1 & 6.0 & 6.9 & 8.0 & 9.1 & 10.3 & 11.4 & 12.3 & 13.1 \\
\hline Guyana & 0.4 & 0.5 & 0.6 & 0.6 & 0.7 & 0.7 & 0.8 & 0.8 & 0.7 & 0.8 & 0.8 & 0.8 \\
\hline Paraguay & 1.5 & 1.7 & 1.9 & 2.2 & 2.5 & 2.8 & 3.2 & 3.7 & 4.3 & 4.8 & 5.4 & 5.9 \\
\hline Perú & 7.6 & 8.7 & 9.9 & 11.5 & 13.2 & 15.2 & 17.3 & 19.5 & 21.8 & 23.9 & 26.0 & 27.8 \\
\hline Surinam & 0.2 & 0.3 & 0.3 & 0.3 & 0.4 & 0.4 & 0.4 & 0.4 & 0.4 & 0.4 & 0.5 & 0.5 \\
\hline Uruguay & 2.2 & 2.4 & 2.5 & 2.7 & 2.8 & 2.8 & 2.9 & 3.0 & 3.1 & 3.2 & 3.3 & 3.3 \\
\hline Venezuela & 5.1 & 6.2 & 7.6 & 9.1 & 10.7 & 12.7 & 15.1 & 17.3 & 19.7 & 22.1 & 24.4 & 26.7 \\
\hline Total & 112.4 & 129.2 & 147.6 & 169.1 & 191.4 & 214.8 & 241.0 & 268.2 & 295.5 & 321.5 & 347.3 & 371.4 \\
\hline Delta (Absolute) & & 16.8 & 18.4 & 21.5 & 22.3 & 23.4 & 26.2 & 27.2 & 27.3 & 26.0 & 25.8 & 24.1 \\
\hline Delta (\%) & & 14.9 & 14.2 & 14.6 & 13.2 & 12.2 & 12.2 & 11.3 & 10.2 & 8.8 & 8.0 & 6.9 \\
\hline
\end{tabular}

Table 4. South America Population Growth 1950 - 2005

Source: (United Nations, 2009)

\begin{tabular}{|c|c|c|c|c|c|c|}
\hline Country & 1950-1970 & 1950-1980 & 1950-1990 & 1950-2005 & 1980-2005 & 1995-2005 \\
\hline Argentina & 1.4 & 1.6 & 1.9 & 2.3 & 1.4 & 1.1 \\
\hline Bolivia & 1.6 & 2.0 & 2.5 & 3.4 & 1.7 & 1.2 \\
\hline Brasil & 1.8 & 2.3 & 2.8 & 3.4 & 1.5 & 1.2 \\
\hline Chile & 1.6 & 1.8 & 2.2 & 2.7 & 1.5 & 1.1 \\
\hline Colombia & 1.8 & 2.2 & 2.8 & 3.6 & 1.6 & 1.2 \\
\hline Ecuador & 1.8 & 2.4 & 3.0 & 3.9 & 1.6 & 1.1 \\
\hline Guyana & 1.7 & 1.8 & 1.8 & 1.8 & 1.0 & 1.0 \\
\hline Paraguay & 1.7 & 2.2 & 2.9 & 4.0 & 1.8 & 1.2 \\
\hline Perú & 1.7 & 2.3 & 2.9 & 3.6 & 1.6 & 1.2 \\
\hline Surinam & 1.7 & 1.7 & 1.9 & 2.3 & 1.4 & 1.1 \\
\hline Uruguay & 1.3 & 1.3 & 1.4 & 1.5 & 1.1 & 1.0 \\
\hline Venezuela & 2.1 & 3.0 & 3.9 & 5.2 & 1.8 & 1.2 \\
\hline Total & 1.7 & 2.1 & 2.6 & 3.3 & 1.5 & 1.2 \\
\hline Delta (Absolute Population) & 79.0 & 128.6 & 183.1 & 259.0 & 130.4 & 49.9 \\
\hline Delta (\% Population) & 70.3 & 114.4 & 162.9 & 230.4 & 54.1 & 15.5 \\
\hline
\end{tabular}


Table 5. South America Population Growth Projections (in millions) 2010 - 2050 Source: (United Nations, 2009)

\begin{tabular}{|c|c|c|c|c|c|c|c|c|c|}
\hline Country & 2010 & 2015 & 2020 & 2025 & 2030 & 2035 & 2040 & 2045 & 2050 \\
\hline Argentina & 40.7 & 42.5 & 44.3 & 45.9 & 47.3 & 48.4 & 49.4 & 50.3 & 50.9 \\
\hline Bolivia & 10.0 & 10.9 & 11.6 & 12.4 & 13.0 & 13.6 & 14.1 & 14.6 & 14.9 \\
\hline Brasil & 195.4 & 202.9 & 209.1 & 213.8 & 217.1 & 219.3 & 220.1 & 220.0 & 218.5 \\
\hline Chile & 17.1 & 17.9 & 18.6 & 19.3 & 19.8 & 20.2 & 20.4 & 20.6 & 20.7 \\
\hline Colombia & 46.3 & 49.4 & 52.3 & 54.9 & 57.3 & 59.2 & 60.8 & 62.0 & 62.9 \\
\hline Ecuador & 13.8 & 14.6 & 15.4 & 16.1 & 16.7 & 17.2 & 17.6 & 17.8 & 18.0 \\
\hline Guyana & 0.8 & 0.8 & 0.7 & 0.7 & 0.7 & 0.7 & 0.6 & 0.6 & 0.6 \\
\hline Paraguay & 6.5 & 7.0 & 7.5 & 8.0 & 8.5 & 8.9 & 9.3 & 9.6 & 9.9 \\
\hline Perú & 29.5 & 31.2 & 32.9 & 34.5 & 36.0 & 37.3 & 38.3 & 39.2 & 39.8 \\
\hline Surinam & 0.5 & 0.5 & 0.6 & 0.6 & 0.6 & 0.6 & 0.6 & 0.6 & 0.6 \\
\hline Uruguay & 3.4 & 3.4 & 3.5 & 3.5 & 3.6 & 3.6 & 3.6 & 3.6 & 3.6 \\
\hline Venezuela & 29.0 & 31.3 & 33.4 & 35.4 & 37.1 & 38.7 & 40.1 & 41.1 & 42.0 \\
\hline Total & 393.0 & 412.4 & 429.9 & 445.1 & 457.7 & 467.7 & 474.9 & 480.0 & 482.4 \\
\hline Delta (Absolute Population) & 21.6 & 19.4 & 17.5 & 15.2 & 12.6 & 10.0 & 7.2 & 5.1 & 2.4 \\
\hline Delta (\% Population) & 5.8 & 4.9 & 4.2 & 3.5 & 2.8 & 2.2 & 1.5 & 1.1 & 0.5 \\
\hline
\end{tabular}

Regarding education in South America, it is worth to review the dynamics of two indicators: the education spending as a percentage of the GDP and the percentage of illiteracy in the population. (See Table 6 and Table 7).

Table 6. South America Education spending as a GDP \% 1991 - 2008.

Sources: (CEPAL, 2009) and (The World Bank, 2008)

\begin{tabular}{|l|c|c|c|c|c|c|c|c|c|c|c|c|}
\hline \multicolumn{1}{|c}{ Country } & $\mathbf{1 9 9 1}$ & $\mathbf{1 9 9 8}$ & $\mathbf{1 9 9 9}$ & $\mathbf{2 0 0 0}$ & $\mathbf{2 0 0 1}$ & $\mathbf{2 0 0 2}$ & $\mathbf{2 0 0 3}$ & $\mathbf{2 0 0 4}$ & $\mathbf{2 0 0 5}$ & $\mathbf{2 0 0 6}$ & $\mathbf{2 0 0 7}$ & $\mathbf{2 0 0 8}$ \\
\hline Argentina & 3.3 & 4.0 & 4.5 & 4.6 & 4.8 & 4.0 & 3.5 & 3.8 &.. & 4.5 &.. &.. \\
\hline Bolivia & 2.4 & 5.5 & 5.7 & 5.5 & 5.9 & 6.2 & 6.4 &.. &.. & 6.3 &.. &.. \\
\hline Brasil &.. & 4.9 & 3.9 & 4.0 & 3.9 & 3.8 &.. & 4.0 & 4.5 & 5.0 &.. &.. \\
\hline Chile & 2.4 & 3.4 & 3.8 & 3.9 &.. & 4.2 & 4.1 & 3.7 & 3.4 & 3.2 & 3.4 &.. \\
\hline Colombia & 2.4 & 3.9 & 4.4 & 3.7 & 3.9 & 4.5 & 4.5 & 4.2 & 4.0 & 3.9 & 4.1 & 3.9 \\
\hline Ecuador & 2.5 & 2.6 & 1.8 & 1.3 & 1.0 &.. &.. &.. &.. &.. &.. &.. \\
\hline Guyana & 2.2 & 8.6 & 8.6 & 8.5 & 8.6 & 8.4 & 7.0 & 5.5 & 8.5 & 8.1 & 6.1 &.. \\
\hline Paraguay & 1.9 & 4.9 & 5.1 & 5.3 & 5.1 & 4.9 & 4.7 & 4.0 &.. &.. &.. &.. \\
\hline Perú & 2.8 & 3.2 & 3.4 &.. & 2.9 & 3.0 & 2.8 & 2.8 & 2.7 & 2.5 & 2.5 &.. \\
\hline Surinam & 5.9 &.. &.. &.. &.. &.. &.. &.. &.. &.. &.. &.. \\
\hline Uruguay & 2.5 & 2.5 & 2.4 & 2.4 & 2.8 & 2.3 & 2.1 & 2.5 & 2.7 & 2.8 &.. &.. \\
\hline Venezuela & 4.6 &.. &.. &.. &.. &.. &.. &.. &.. & 3.6 & 3.7 &.. \\
\hline \multicolumn{1}{|c|}{ Average } & $\mathbf{3 . 0}$ & $\mathbf{4 . 4}$ & $\mathbf{4 . 4}$ & $\mathbf{4 . 4}$ & $\mathbf{4 . 3}$ & $\mathbf{4 . 6}$ & $\mathbf{4 . 4}$ & $\mathbf{3 . 8}$ & $\mathbf{4 . 3}$ & $\mathbf{4 . 4}$ & $\mathbf{4 . 0}$ & $\mathbf{3 . 9}$ \\
\hline
\end{tabular}


Tabla 7. South America Illiteracy as a Population \% 1970 - 2010.

Sources: (CEPAL, 2009) and (The World Bank, 2008)

\begin{tabular}{|l|r|r|r|r|r|r|r|}
\hline \multicolumn{1}{|c|}{ Country } & $\mathbf{1 9 7 0}$ & $\mathbf{1 9 8 0}$ & $\mathbf{1 9 9 0}$ & $\mathbf{1 9 9 5}$ & $\mathbf{2 0 0 0}$ & $\mathbf{2 0 0 5}$ & $\mathbf{2 0 1 0}$ \\
\hline Argentina & 7.0 & 5.6 & 4.3 & 3.7 & 3.2 & 2.8 & 2.4 \\
\hline Bolivia & 42.5 & 31.3 & 21.9 & 17.9 & 14.6 & 11.7 & 9.4 \\
\hline Brasil & 31.6 & 24.0 & 18.0 & 15.3 & 13.1 & 11.1 & 9.6 \\
\hline Chile & 12.4 & 8.6 & 6.0 & 5.1 & 4.2 & 3.5 & 2.9 \\
\hline Colombia & 22.2 & 16.0 & 11.6 & 9.9 & 8.4 & 7.1 & 5.9 \\
\hline Ecuador & 25.7 & 18.1 & 12.4 & 10.2 & 8.4 & 7.0 & 5.8 \\
\hline Guyana & 9.3 & 5.4 & 2.8 & 2.1 & 1.5 & 1.0 & 0.7 \\
\hline Paraguay & 20.2 & 14.1 & 9.7 & 8.1 & 6.7 & 5.6 & 4.7 \\
\hline Perú & 28.5 & 20.6 & 14.5 & 12.2 & 10.1 & 8.4 & 7.0 \\
\hline Surinam &.. &.. &.. &.. &.. & 10.4 & 9.3 \\
\hline Uruguay & 6.7 & 5.0 & 3.5 & 2.9 & 2.4 & 2.0 & 1.7 \\
\hline Venezuela & 23.7 & 16.1 & 11.1 & 9.1 & 7.5 & 6.0 & 4.8 \\
\hline \multicolumn{1}{|c|}{ Average } & $\mathbf{2 0 . 9}$ & $\mathbf{1 5 . 0}$ & $\mathbf{1 0 . 5}$ & $\mathbf{8 . 8}$ & $\mathbf{7 . 3}$ & $\mathbf{6 . 4}$ & $\mathbf{5 . 4}$ \\
\hline
\end{tabular}

The education spending increase around $35 \%$ in the nineties to remain relatively stable during the last 10 years, whereas the illiteracy was reduced $75 \%$ in the last 40 years, from $20,9 \%$ in 1970 to $5,9 \%$ in 2010 . This change and stabilization of the education indicators can allow the region to advance from the actions to eliminate urgent social problems to the strategic planning and action of, for example, the education for sustainability.

Poverty and Inequality has become one of the main South American problems. It is hard to define poverty and inequality based on global benchmarking and for the purpose of this paper the use of national poverty lines (See Table 8) and GINI coefficients (See Table 9) are the two main indicators to study this systemic structure and dynamics.

There are new and innovative contemporary approaches to understand poverty like the one from Manfred Max-Neef (Max-Neef, Elizalde, \& Hopenhayn, 1994) based on multiple and simultaneous poverty situations caused by the human needs/satisfactors imbalances or Amartya Sen's multi-dimensional poverty based on the capabilities approach to welfare (Sen, 1979) that is reflected on the development of the Human Development Index that is show for South America on Table 10.

Another more recent way of measuring poverty is one related to the use of resources versus the bio capacity of a geographical region. Developed by the Global Footprint Network it is called the Ecological Wealth of Nations (EWN) and it is shown for South American countries on Tables 11 and 12. 
South America is an ecological, economic and social region of which we have an incomplete history of his structure and dynamics. Advances have become important and thus, for example, for a search of data in the World Bank World Development Indicators database of 2008 (The World Bank, 2008), in the general consultation that is formed by 26 indicators, for the period 1960 to 2007 there exists an availability of $51 \%$ of the data for the 12 countries considered.

Table 8. South America Poverty \% 1979 - 2008.

Sources: (CEPAL, 2009) and (The World Bank, 2008)

\begin{tabular}{|l|r|r|r|r|r|r|r|r|r|r|r|r|r|r|r|r|r|}
\hline \multicolumn{1}{|c}{ Country } & $\mathbf{1 9 7 9}$ & $\mathbf{1 9 8 0}$ & $\mathbf{1 9 8 6}$ & $\mathbf{1 9 8 7}$ & $\mathbf{1 9 9 0}$ & $\mathbf{1 9 9 4}$ & $\mathbf{1 9 9 6}$ & $\mathbf{1 9 9 7}$ & $\mathbf{1 9 9 9}$ & $\mathbf{2 0 0 1}$ & $\mathbf{2 0 0 3}$ & $\mathbf{2 0 0 4}$ & $\mathbf{2 0 0 5}$ & $\mathbf{2 0 0 6}$ & $\mathbf{2 0 0 7}$ & $\mathbf{2 0 0 8}$ \\
\hline Argentina &.. & 10.4 &.. &.. & 30.0 &.. &.. &.. & 28.0 &.. & 46.0 &.. & 32.0 &.. &.. & 34.0 \\
\hline Bolivia &.. &.. &.. &.. &.. &.. &.. & 62.1 & 60.6 &.. & 63.9 & 63.9 &.. &.. & 54.0 &.. \\
\hline Brasil & 45.1 &.. &.. &. &. & 48.0 &. & 35.8 &.. & 37.5 & 37.5 & 38.7 & 37.7 & 36.3 & 33.3 & 30.0 & 25.8 \\
\hline Chile &.. &.. &.. & 45.1 & 38.6 & 27.6 & 23.2 &.. &.. &.. & 18.7 &.. &.. & 13.7 &.. &.. \\
\hline Colombia &.. & 42.3 &.. &.. &.. & 52.5 &.. & 50.9 & 54.9 &.. &.. & 51.1 & 46.8 &.. &.. &.. \\
\hline Ecuador &.. &.. &.. &.. &.. &.. &.. &.. &.. &.. &.. & 51.2 & 48.3 & 43.0 & 42.6 & 42.7 \\
\hline Guyana &.. &.. &.. &.. &.. &.. &.. &.. &.. &.. &.. &.. &.. &.. &.. &.. \\
\hline Paraguay &.. &.. &.. &.. &.. &.. &.. &.. & 60.6 & 61.0 &.. & 65.9 & 60.5 &.. & 60.5 & 58.2 \\
\hline Perú & 52.9 &.. & 59.9 &.. &.. &.. &.. & 47.6 & 48.6 & 54.8 & 54.7 & 48.6 & 48.7 & 44.5 & 39.3 & 36.2 \\
\hline Surianam &.. &.. &.. &.. &.. &.. &.. &.. &.. &.. &.. &.. &.. &.. &.. &.. \\
\hline Uruguay &.. &.. & 20.4 &.. &.. &.. &.. &.. &.. &.. &.. &.. &.. &.. & 17.7 & 13.7 \\
\hline Venezuela &.. &.. & 32.2 &.. & 39.8 & 48.7 &.. & 48.0 & 49.4 &.. &.. & 45.4 & 37.1 & 30.2 & 28.5 & 27.6 \\
\hline
\end{tabular}

Table 9. South America GINI trends 1985 - 2005

Sources: (The World Bank, 2008), (FAO, 1994) and (United Nations, 1990-2009)

\begin{tabular}{|l|c|c|c|c|c|}
\hline Country & $\begin{array}{c}\text { GINI } \\
\text { 1967-1985 }\end{array}$ & $\begin{array}{c}\text { GINI } \\
\mathbf{1 9 7 5 - 1 9 8 8}\end{array}$ & $\begin{array}{c}\text { GINI } \\
\mathbf{2 0 0 1}\end{array}$ & $\begin{array}{c}\text { GINI } \\
\mathbf{2 0 0 5}\end{array}$ & $\begin{array}{c}\text { Land } \\
\text { GINI } \\
\mathbf{1 9 8 5 - 1 9 9 3} \\
\text { (year) }\end{array}$ \\
\hline Argentina & & &.. & 51.3 & $83(88)$ \\
\hline Bolivia & & & 58.9 & 60.1 & \\
\hline Brasil & 57 & 57 & 59.1 & 57.0 & $85(85)$ \\
\hline Chile & 46 & 46 & 57.5 & 54.9 & \\
\hline Colombia & 45 & & 57.1 & 58.6 & $79(88)$ \\
\hline Ecuador & & & 43.7 & 53.6 & \\
\hline Guyana & & & 40.2 &.. & \\
\hline Paraguay & & & 57.7 & 58.4 & $93(91)$ \\
\hline Perú & 31 & 31 & 46.2 & 52.0 & $86(94)$ \\
\hline Surinam & & &.. &.. & \\
\hline Uruguay & & & 42.3 & 44.9 & \\
\hline Venezuela & & & 48.8 & 48.2 & \\
\hline
\end{tabular}


Table 10. South America HDI trends 1960 - 1987

Sources: (United Nations, 1990-2009)

\begin{tabular}{|c|c|c|c|c|c|c|c|c|c|c|c|c|c|c|}
\hline Country & 1960 & 1970 & 1975 & 1980 & 1985 & 1990 & 1995 & 2000 & 2005 & 2006 & 2007 & $\begin{array}{c}1960- \\
2007 \\
(\%)\end{array}$ & $\begin{array}{c}1985- \\
2007 \\
(\%)\end{array}$ & $\begin{array}{c}2000- \\
2007 \\
(\%)\end{array}$ \\
\hline Argentina & 0.667 & 0.748 & 0.776 & 0.793 & 0.797 & 0.804 & 0.824 & 0.856 & 0.855 & 0.861 & 0.866 & 29.8 & 8.7 & 1.2 \\
\hline Bolivia & 0.308 & 0.369 & 0.524 & 0.560 & 0.577 & 0.629 & 0.653 & 0.699 & 0.723 & 0.726 & 0.729 & 136.7 & 26.3 & 4.3 \\
\hline Brasil & 0.394 & 0.507 & 0.639 & 0.685 & 0.694 & 0.710 & 0.734 & 0.790 & 0.805 & 0.808 & 0.813 & 106.3 & 17.1 & 2.9 \\
\hline Chile & 0.584 & 0.682 & 0.702 & 0.748 & 0.762 & 0.795 & 0.822 & 0.849 & 0.872 & 0.874 & 0.878 & 50.3 & 15.2 & 3.4 \\
\hline Colombia & 0.469 & 0.554 & 0.657 & 0.688 & 0.698 & 0.715 & 0.757 & 0.772 & 0.795 & 0.800 & 0.807 & 72.1 & 15.6 & 4.5 \\
\hline Ecuador $^{*}$ & 0.422 & 0.485 & 0.645 & 0.709 & 0.723 & 0.744 & 0.758 & 0.781 & 0.804 & 0.805 & 0.806 & 91.0 & 11.5 & 3.2 \\
\hline Guyana & .. & .. & 0.676 & 0.679 & 0.668 & 0.670 & 0.685 & 0.714 & 0.722 & 0.721 & 0.729 & .. & 9.1 & 2.1 \\
\hline Paraguay & 0.474 & 0.511 & 0.655 & 0.677 & 0.677 & 0.711 & 0.726 & 0.737 & 0.754 & 0.757 & 0.761 & 60.5 & 12.4 & 3.3 \\
\hline Perú & 0.420 & 0.528 & 0.641 & 0.687 & 0.703 & 0.708 & 0.744 & 0.771 & 0.791 & 0.799 & 0.806 & 91.9 & 14.7 & 4.5 \\
\hline Surinam & .. & .. & .. &.. & .. & 0.751 & .. & 0.756 & 0.759 & 0.765 & 0.769 & .. & .. & 1.7 \\
\hline Uruguay & 0.737 & 0.762 & 0.759 & 0.776 & 0.783 & 0.802 & 0.817 & 0.837 & 0.855 & 0.860 & 0.865 & 17.4 & 10.5 & 3.3 \\
\hline Venezuela & 0.600 & 0.728 & 0.740 & 0.765 & 0.765 & 0.790 & 0.793 & 0.802 & 0.822 & 0.833 & 0.844 & 40.7 & 10.3 & 5.2 \\
\hline Average & $\begin{array}{l}0.508 \\
\end{array}$ & 0.587 & 0.674 & 0.706 & 0.705 & 0.736 & 0.756 & 0.780 & 0.796 & 0.801 & 0.806 & 69.7 & 13.8 & 3.3 \\
\hline
\end{tabular}

Table 11. South America Ecological Footprint and Biocapacity trends 1991 - 2006

Sources: (Global Footprint Network, 2010), (World Wide Fund, 2004), (World Wide Fund, 2006) and (World Wide Fund, 2008)

\begin{tabular}{|c|c|c|c|c|c|c|c|c|c|c|}
\hline \multirow[t]{2}{*}{ Country } & \multicolumn{5}{|c|}{$\begin{array}{c}\text { Ecological Footprint } \\
\text { (global hectares per capita) }\end{array}$} & \multicolumn{5}{|c|}{$\begin{array}{c}\text { Biocapacity } \\
\text { (global hectares per capita) }\end{array}$} \\
\hline & 1991 & 2001 & 2003 & 2005 & 2006 & 1991 & 2001 & 2003 & 2005 & 2006 \\
\hline Argentina & 2.8 & 2.6 & 2.3 & 2.5 & 3.0 & 7.2 & 6.7 & 5.9 & 8.1 & 7.1 \\
\hline Bolivia & 1.1 & 1.2 & 1.3 & 2.1 & 2.4 & 19.0 & 15.6 & 15.0 & 15.7 & 19.3 \\
\hline Brasil & 2.0 & 2.2 & 2.1 & 2.4 & .. & 11.3 & 10.2 & 9.9 & 7.3 & \\
\hline Chile & 2.0 & 2.6 & 2.3 & 3.0 & 3.1 & 6.4 & 5.5 & 5.4 & 4.1 & 4.1 \\
\hline Colombia & 1.3 & 1.3 & 1.3 & 1.8 & 1.9 & 4.4 & 3.7 & 3.6 & 3.9 & 3.9 \\
\hline Ecuador & 1.5 & 1.8 & 1.5 & 2.2 & 1.9 & 2.8 & 2.1 & 2.2 & 2.1 & 2.3 \\
\hline Guyana & 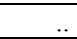 & .. & .. & .. & .. & .. &.. & .. &.. & .. \\
\hline Paraguay & 2.2 & 2.2 & 1.6 & 3.2 & 3.4 & 6.9 & 5.7 & 5.6 & 9.7 & 10.8 \\
\hline Peru & 0.9 & 0.9 & 0.9 & 1.6 & 1.8 & 5.0 & 4.3 & 3.8 & 4.0 & 4.1 \\
\hline Surinam & ... & .. & .. & .. & .. & .. & .. & .. & .. & \\
\hline Uruguay & 2.5 & 2.6 & 1.9 & 5.5 & .. & 7.7 & 7.5 & 8.0 & 10.5 & \\
\hline Venezuela & 2.4 & 2.4 & 2.2 & 2.8 & 2.3 & 3.0 & 2.5 & 2.4 & 3.2 & 2.7 \\
\hline
\end{tabular}


Table 12. South America Ecological Wealth trends 1991 - 2006

\begin{tabular}{|l|r|r|r|r|r|}
\hline \multirow{3}{*}{ Country } & \multicolumn{5}{|c|}{$\begin{array}{c}\text { Ecological Weath } \\
\text { (global hectares per capita) }\end{array}$} \\
\cline { 2 - 6 } & $\mathbf{1 9 9 1}$ & $\mathbf{2 0 0 1}$ & $\mathbf{2 0 0 3}$ & $\mathbf{2 0 0 5}$ & $\mathbf{2 0 0 6}$ \\
\hline Argentina & 4.4 & 4.1 & 3.6 & 5.6 & 4.1 \\
\hline Bolivia & 17.9 & 14.4 & 13.7 & 13.6 & 16.9 \\
\hline Brasil & 9.3 & 8.0 & 7.8 & 4.9 &.. \\
\hline Chile & 4.4 & 2.9 & 3.0 & 1.1 & 1.0 \\
\hline Colombia & 3.1 & 2.4 & 2.3 & 2.1 & 2.0 \\
\hline Ecuador & 1.3 & 0.3 & 0.7 & $(0.1)$ & 0.4 \\
\hline Guyana &.. &.. &.. &.. &.. \\
\hline Paraguay & 4.6 & 3.5 & 4.0 & 6.5 & 7.4 \\
\hline Perú & 4.1 & 3.4 & 3.0 & 2.4 & 2.3 \\
\hline Surinam &.. &.. &.. &.. &.. \\
\hline Uruguay & 5.2 & 4.9 & 6.1 & 5.0 &.. \\
\hline Venezuela & 0.7 & 0.1 & 0.2 & 0.4 & 0.3 \\
\hline
\end{tabular}

\section{First Results and Discussion}

The tools of first-order cybernetics (boundaries, sub- and supra-systems, circular causality, positive and negative feedback and simulation), and of the second-order cybernetics (self-reference, self-steering, self-organization, self-catalysis and autopoiesis) helps to understand in new ways the structure and dynamics of South America.

In particular, they help for modeling complex problems as poverty and artificial sustainability with tools such as System Dynamics, because they require determining and specifying boundaries, sub- and supra-systems, causality and positive or negative feedback, even though it is not clear the way to follow in order to analyze and synthesize these models in relation to second-order cybernetics; it is not clear how the evolution of an autopoietic system can breed another autopoietic system and it is not clear what type of scales are involved. However, in some way, the observer can observe or change the steady state of the observed system.

For example, as we have seen from the South America data, poverty is an autopoietic phenomenon in the region and, a first look at the regional scale, shows that the speed of change on population growth is a key factor to determine poverty on a local scale. On the other hand, education investment, a factor considered as a very important determinant for reducing poverty, seems related to it but it is not clear how and more analysis is needed in order to find the systemic internal acting mechanisms.

Observing the Human Development Indicators at regional scale one can find that it approaching a steady state below the higher ideal and needed values and that this 
autopoietic situation need some sort on innovative structural changes to make it possible to pass the 0.900 threshold.

Not considered here in this paper but at task at hand within this research, is the relationship between poverty and belief, religious and cultural behaviors at local and regional scales in South America. It is possible that the innovative structural changes needed to reach higher human quality of life in the region could be related to those behaviors but more extensive and decisive research is needed.

It is possible to say that South America has been a 'natural' sustainable region of planet Earth based on its Ecological Wealth Indicators, but its fast population growth inertia aimed to last for a least another 15+ years, adding 3,500,000 inhabitants per year on average, with a Needs-to-Wants population mobility with no clear direction, speed or acceleration figures from the GINI data, make it uncertain to say what will be the situation on the near future.

Then, it is also possible to say that in the next 20 years, South America will have to change its systemic structure and dynamics from a 'natural' to an 'artificial' sustainability steady state framework based on the Ecological Wealth Indicators that shows most of the countries of the region headed towards a human footprint increase and a bio capacity decrease, even without reducing poverty.

The danger zone South America is entering based on its population and bio capacity dynamics trends, is no different of the danger zone the whole planet is in. As (Fernández, 2007) point out, 'nature' sustainability is different than human 'artificial' sustainability because nature's way of sustainability encompasses catastrophic implications to humans such as pandemics, famines, drought, and weather related disasters. Once crossed the threshold of natural steady states feedbacks, checks and balances, then the last 3,000 years are no longer benchmarks for human expectations.

Meanwhile (Fernández, 2007) government, industry and academia are busy with transformation: that's it, developing the so called sustainable processes of highperformance green economy, of getting out of poverty millions of people.

\section{Conclusions}

There is a relationship between system and subsystem dynamics direction, speed and acceleration change at different space and time scales and its related sustainability situations, not only locally but globally. New sustainable steady states depend on using 
not only natural but also artificial sustainability approaches. Intelligence is a key factor.

Exploring South America's system dynamics direction, speed and acceleration changes helps to understand the relationship between social, economical and ecological subsystems and enriches the sustainability science research bringing up new questions and situations, not only about the observed system but also of the internal and external observers as key actors of the possible systemic structure interventions. For example, education investment is strategic, but seems to have poor results is used alone for poverty reduction. Something is missing.

Natural-to-artificial sustainability conceptual thinking is an approach based on observer behavior observation, and makes sociocybernetics a key framework to handle the complex systemic problems of which the observer is part of the system. Human sustainability is a second order cybernetic problem and can't be solved with only first order tools. The tools exist.

Reducing poverty following a sustainable path not only will require a change on the methods poverty is defined and measured but on the way the humans live. If people want to have a longevity of $60+$ year on average without affecting the bio capacity systemic steady state, multidimensional human scale development not only have to change the needs-to-wants structure and dynamics but also the way 'natural' and 'artificial' is assumed by humans. Contemporary poverty reduction is not sustainable.

Natural and artificial sustainability are based on system steady states. Artificial is understood here as a natural product of human efforts by means of human intelligence or, in other words, a human intelligence way to find new natural steady states. For the first time humans, the observers of that 'natural world', has become aware that they can change the observed system but only changing the observing system, themselves. Maybe $99 \%$ of human population isn't aware of the imminent needed change.

\section{References}

Amit, S. (2008). Artificial vs. Natural. Retrieved Junio 7, 2010, from Reason for Liberty: http://www.reasonforliberty.com/philosophy/artificial-vs-natural.html

CEPAL. (2009, 09 14). CEPALSTAT Base de datos y publicaciones Estadísticas. Retrieved 02 10, 2010, from Comision Económica para América Latina y el Caribe:

http://websie.eclac.cl/infest/cepalstat.html 
Costanza, R., \& Patten, B. C. (1995). Defining and predicting sustainability. Ecological Economics, 15, 193-196.

Coutts, D. A. (2009, 10 8). The exponentialist. Retrieved 06 2010, from $\mathrm{http}: / /$ members.optusnet.com.au/exponentialist/index.htm

Dawkins, R. (2001, Noviembre 14). Sustainability doesn't come naturally: a Darwinian Perspective on Values. The values platform for sustainability - Inaugural Lecture, The Enviroment Foundation, Londres.

FAO. (1994). World Census of Agriculture. Retrieved 03 15, 2010, from Food and Agriculture Organization (FAO) Programme for the Census of Agriculture (WCA): http://www.fao.org/economic/ess/world-census-of-agriculture/en/

Fernández, J. L. (2007). Definition of Natural and Artificial Sustainability as the force that tames an exponentialoid. The Construction and Building Research Conference of the Royal Institution of Chartered Surveyors. Atlanta, GA: RICS; Georgia Tech.

Gallón, L. (2009). Space and Time scales of Human perspective and Sustainability: Tools for modeling daily life dynamics. 9th Internacion Conference of Sociocybernetics 'MODERNITY 2.0': Emerging social media technologies and their impacts. Urbino, Italy.

Global Footprint Network. (2010). The Ecological Wealth of Nations: Earth's biocapacity as a new framework for international cooperation. (S. Goldfinger, \& P. Poblete, Eds.) Washington, DC, USA.

Max-Neef, M. A., Elizalde, A., \& Hopenhayn, M. (1994). Desarrollo a escala humana: conceptos, aplicaciones y algunas reflexiones. Barcelona; Montevideo: Icaria; NordanComunidad.

Meadow, D. H., Meadows, D. L., \& Randers, J. (2004). Limits to Growth - the 30-Year Update. White River Junction, VT, USA: Chelsea Green Publishing Co.

Population Reference Bureau. (2008). World Population Clock, 2008. Retrieved 02 15, 2010, from http://www.prb.org/Articles/2008/WorldPopulationClock2008.aspx

Sen, A. (1979, 5 22). Equality of What? The Tanner Lecture on Human values. Palo Alto, CA, USA: Stanford University.

The World Bank. (2008). 2008 World Development Indicators (WDI).

United Nations. (1990-2009). Human Development Report. Retrieved 04 20, 2010, from United Nations Development Program (UNDP): http://hdr.undp.org/en/

United Nations. (2009, 03 11). World Population Prospects: 2008 Revision Population Database. Retrieved 06 10, 2010, from United Nations Population Division: http://esa.un.org/unpp/index.asp

von Bertalanffy, L. (1976). Teoría general de los sistemas: Fundamentos, desarrollo, aplicaciones (1 ed.). (J. Almela, Trad.) México, D.F., México: Fondo de Cultura Económica. 


\section{Luciano Gallon}

Wikipedia. (9 de 4 de 2010). Steady State. Recuperado el 5 de 2010, de http://en.wikipedia.org/wiki/Steady_state

World Wide Fund. (2004). Living Planet Report. Gland.

World Wide Fund. (2006). Living Planet Report. Gland.

World Wide Fund. (2008). Living Planet Report. Gland. 